\title{
A survey of Interlibrary Loans at Ruđer Bošković Institute Library, Croatia, 2003-2008
}

Bojan Macan and Sofija Konjević

Ruđer Bošković Institute, Library, Bijenička cesta 54, 10000 Zagreb, Croatia

\begin{abstract}
Purpose- The purpose of this survey is to evaluate the efficiency and effectiveness of interlibrary loan (ILL) at the RBI Library in Croatia.

Design/methodology/approach - Various indices were measured including: the percentage of fulfilled ILL requests, the difference between copy and loan requests, the difference between requests fulfilled free of charge and fee based and also to calculate the document delivery time. The analyzed data on received ILL requests were gathered via an inhouse developed application for ILL called SEND, via which RBI researchers submit their ILL requests to the RBI Library.
\end{abstract}

Findings - This survey showed a high percentage of fulfilled ILL requests $(94.6 \%)$, but there was also a surprisingly high percentage of cancelled ILL requests, because RBI Library owned the requested documents (21.8\%). Most ILL requests were copy requests and the analysis of the gathered data showed a trend of acquiring more documents free of charge. Delivery time has decreased in the period of the survey, and in 2008, it was less than 6 working days for copy requests and approximately 10 days for loan requests. The delivery time was shorter for fee based requests.

Originality/value - This paper presents a systematic analysis of ILL service of the RBI Library for a six year period (2003-2008).

Keywords document supply, electronic document delivery, Ruđer Bošković Institute, interlibrary loan, Croatia

Paper type Research paper

\section{Introduction}

Croatia is an EU candidate country with a population of 4.4 million. Its gross domestic product (GDP) per capita in 2008 was $€ 10.678$, while the annual growth rate in GDP was 2.4\%. Total investment in research and development (R\&D) in 2007 reached 2.5 billion Croatian kunas (approximately $€ 348$ m.), of which 47.3\% came from the government. In 2007 Croatia had 9,199 full-time researchers (11,109 including part-time researchers and researchers under contract) and they published 10,560 research papers. The total number of R\&D units in 2007 was 199, 115 of which were institutions of higher education, (CrkvenčićBojić ed., 2009). In the academic year 2008/09, there were seven universities in Croatia in Zagreb, Split, Rijeka, Osijek, Dubrovnik, Zadar and Pula, with 78 faculties and 6 Academies of Art, as well as 15 polytechnics and 27 schools of higher education. These 126 institutions of higher education had 134,188 students in 2008/9 enrolled in academic studies. The number of academic staff for the same period was 14,995, (Crkvenčić-Bojić (ed.), 2009).

Ruđer Bošković Institute (RBI) was founded in 1950 and today it is the largest national research centre in Croatia in the field of basic and applied science. It consists of 
eleven divisions, three centers, a library, section for maintenance, technical services and administration. The Institute is primarily located in Zagreb, except for the Center for Marine Research located in Rovinj along with a library department. RBI is a multidisciplinary public research institute and is funded mainly by the Croatian Ministry of Science, Education and Sports. In 2008 there were 530 scientists (375 researchers and 155 undergraduate students) working in physics, chemistry, oceanography (including marine and environmental research and geosciences), biology, biomedicine, computer science and electronics/engineering. Scientists from the Institute participated in 78 undergraduate courses and 245 graduate and postgraduate courses in Croatia. Scientific output in 2008 consisted of 446 research papers published mostly in high ranked international journals, (Pivac (ed.), 2009).

Ruđer Bošković Institute Library (RBI Library) was founded in 1950, the same year as the Institute itself and today it is the largest Croatian scientific library in the field of natural sciences. It satisfied all information needs of RBI staff by providing various information services and access to relevant literature. At the moment Library provides access to more than 16,000 fee and free e-journals, 40 databases and 42 e-books. Print holding consist of 22,474 monographs and 1,200 print journals, but only 77 of which are current.

Because of the proliferation of full text journals in the last ten years, a decrease in ILL requests at the RBI was expected, which is confirmed by surveys in other libraries (Echeverria and Barredo 2005; Jackson, 2004); however some surveys showed the opposite - a stagnation or even an increase in ILL requests (Jackson, 2004; Wiley and Chrzastowski, 2005; Yue and Syring, 2004). The analysis in this article will contribute the experience of RBI to this debate.

Although a great part of recent scientific information is available electronically and therefore just one click away from the end-users, the main obstacle is the high subscription price of journals. Subscriptions for journals published by commercial publishers are growing constantly at an annual average of $7.6 \%$, (Glenn et al., 2008) while library budgets are decreasing. As a consequence, libraries are forced to cut journal subscriptions. Therefore, the end users are again facing a literature shortage and the ILL service increases in importance among library services. As an alternative to commercial publishing, Open Access has emerged, as well as Institutional Repositories, both of which are increasing in popularity. Time will tell if alternative publishing reduces the need for an ILL service.

No library in the world can provide all the information resources that their users need. In order to achieve good cooperation with domestic and foreign libraries RBI Library has developed an effective ILL service and has offered it to its users from the very beginning; the first ILL records go back to 1965. In 1981, two posters regarding ILL were presented, showing the most used journals and the most frequently used lending libraries at the time, (Topolčić et al., 1981a, 1981b). The ILL service of RBI Library was presented in three papers published in the journal Kemija u industriji (Chemistry in Industry), and one paper published in conference proceedings (Borić, 1999; Konjević, 2009; Mayer, 2008; Mihalić, 2009).

RBI Library has a well-established cooperation with other libraries, mainly from Croatia, but also from abroad. The closest cooperation has been developed among the libraries from the former Croatian Sciences Information System project (CSIS). This project, supported by the Croatian Ministry of Science, Education and Sports, started in 1994 and supported the implementation of new technologies and improving library services among more than 120 Croatian academic and research libraries. The RBI Library provides an ILL 
service from other libraries' collections, but only to RBI staff. In return all materials from the RBI Library are available to all other libraries.

The British Library was among the first foreign libraries with which the RBI Library established ILL cooperation back in 1993. From 1996 to 1999, the library participated in the German project "Bibliotheken und wisenschaftlichen Bibliotheken in Mittel- und Osteuropa", and one of the advantages was obtaining material via ILL from the German National Library of Medicine, German National Library of Science and Technology (TIB) and The University Library of Bochum. At that time, these libraries contributed to the Subito catalogue that gave RBI the opportunity to become familiar with the service. A few years later, in 2004, RBI Library subscribed to Subito. RBI Library also has, or had, cooperation with Slovenian libraries: Central Medical Library, Central Technological library, and "Jožef Stefan" Institute. In the last few years, cooperation with the libraries of the European Association of Aquatic Sciences Libraries and Information Centres (EURASLIC) as well as those of the International Association of Aquatic and Marine Science Libraries and Information Centers (IAMSLIC) has been very intensive.

In most cases Croatian libraries have an informal reciprocal agreement and the ILL service is either free of charge, or sometimes just handling fees are charged. The EURASLIC/ IAMSLIC community also provides an ILL service on a reciprocal basis free of charge. All other partner libraries charge for the service either by advance payment or monthly account. The IFLA Voucher Scheme has not yet been implemented as there is little use of it. When payment by IFLA voucher is the only possibility, items are requested through the National and University Library in Zagreb.

If the requested material is not found within the partner libraries, then non-partner library catalogues are searched (e.g. The European Library, national union catalogues, etc.). Once the material is located, the owning (non-partner) library is contacted directly to negotiate the terms of ILL.

In order to facilitate and speed up the process of ordering documents via ILL, the RBI Library has developed a web application as a support for the electronic ordering of documents called Electronic Documents Acquiring System - SEND (http://send.irb.hr) (See Figure 1). SEND allows authorized users (RBI staff) to request documents from Croatian libraries or abroad and for authorized Croatian libraries to request documents owned by the RBI Library. After logging in, authorized users must complete an online form with the bibliographic details and select whether they accept fee based acquisition of documents, if they are not available free of charge. Once the requested document is received, an email is sent automatically by the system to the user. 


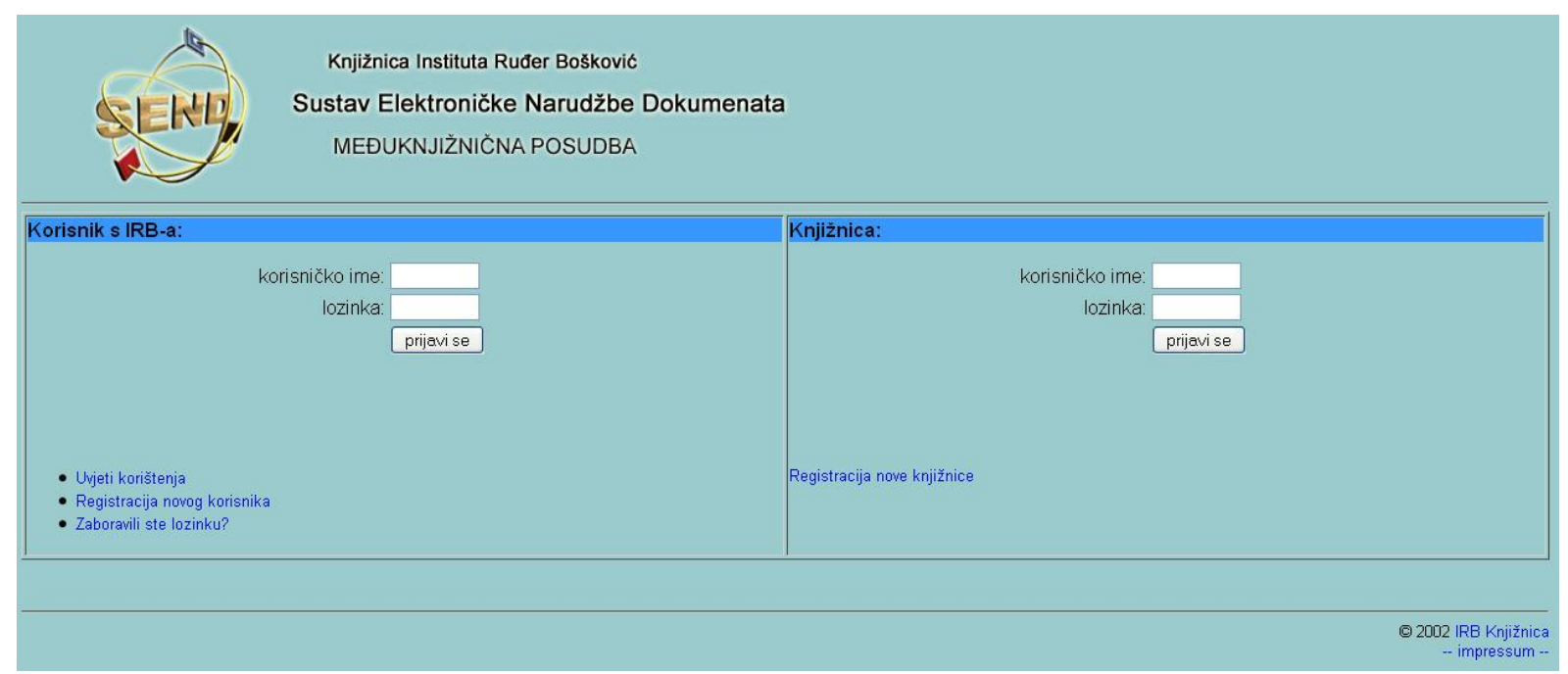

Figure 1: Electronic Documents Acquiring System Homepage (SEND)

SEND was launched in December 2002 and three days later, there were 56 registered users, (Borić and Pranjić, 2003). By 2010, there were 385 registered RBI employees, 75 lending libraries (including two assemblies of libraries - Subito ${ }^{1}$ and IAMSLIC catalogue ${ }^{2}$ ) and 55 requestor libraries.

Thanks to SEND, orders can be made through a simple interface from the user's desktop or any other place, at any time, regardless of library working hours. Automation allows the Library to control ILL requests, the online service allows users and library staff to track the request status, and the Library has gained a simple tool for gathering statistical data.

\section{Research}

\subsection{Introduction}

The aim of this research was to gather information about ILL and to identify the trends in various aspects of ILL at the RBI Library. The research issues are:

- the use of the ILL service at the RBI

- the ratio of copy and loan ILL requests

- the percentage of fulfilled ILL requests

- the ratio of fulfilled ILL requests from Croatian and foreign libraries

- the ratio of ILL requests fulfilled free of charge and those fee based

- the processing and delivery time for ILL requests.

\subsection{Research methodology}

\footnotetext{
${ }^{1}$ Subito consists of 39 supplier libraries for the Subito customer service, 78 supplier libraries for the Subito Library Service (http://www.subito-doc.de/index.php?lang=en\&mod=page\&pid=Lieferantenprofile) (accessed 9 June, 2010)

${ }^{2}$ IAMSLIC catalogue consists of 26 library catalogues that support the Z39.50 protocol and 66 libraries that provide a list of journals as their catalogues are not compliant with the Z39.50 protocol (http://library.csumb.edu/iamslic/ill/liblist.php) (accessed 9 June, 2010)
} 
From January $1^{\text {st }} 2003$ to December $31^{\text {st }} 2008$, the data on ILL requests submitted via SEND by RBI researchers and requested from other libraries were gathered and analyzed. The 6-year period was chosen because SEND was launched at the end of 2002, so the year 2003 was the first year with complete statistical data about RBI's ILL requests.

The following data were analyzed: data about lending libraries, time needed to order an item from another library (processing time), time needed for users to obtain the requested item (delivery time) and data about how many orders were requested only if the items could be acquired free of charge. By "free of charge" we mean acquisition on a reciprocal basis, under the deal that the RBI Library has with all Croatian libraries and EURASLIC/IAMSLIC libraries.

Lending libraries are divided according to several criteria. The first criterion is the country of origin (Croatian libraries and foreign libraries). Croatian libraries are further divided according to CSIS classification into Natural Sciences, Biomedicine, Technical Sciences, Social Sciences and Humanities. The second criterion is ILL price, under which libraries with established free reciprocal ILL and libraries that charge for the ILL service can be distinguished.

The data were analyzed in Microsoft Excel. Requests submitted for the items available in the RBI library are excluded from the analysis, unless indicated otherwise.

\subsection{Research results and discussion}

In the 6-year period the RBI Library received 4,918 ILL requests from RBI staff, 4,595 were copy requests (mostly journal articles) and 323 loan requests (mostly monographs), (See Figure 2). In this period, the ILL application SEND was used for requesting documents by 289 employees of the RBI, which is over half (54.5\%) the research staff in 2008. The real number of the RBI ILL users is probably even higher because it is not unusual for junior researchers to order documents for senior researchers from their own account.

Of the 4918 ILL requests, $1,070(21.8 \%)$ were cancelled because they were owned by the RBI Library; of these 1,021 were copy requests and 49 loan requests. The reasons for cancellations were twofold; the first was that 111 of the requested items were at a separate library department in Rovinj so they were requested internally (106 copies, 5 loan), and the second, was that 959 cancellations occurred because the RBI Library already had the printed journal/book or had access to the requested e-content.

If the cancelled requests are excluded, the total number of ILL requests requested from Croatian or foreign libraries was 3,848, (3,574 copies and 274 loans). The ratio of copies to books was 13:1. 


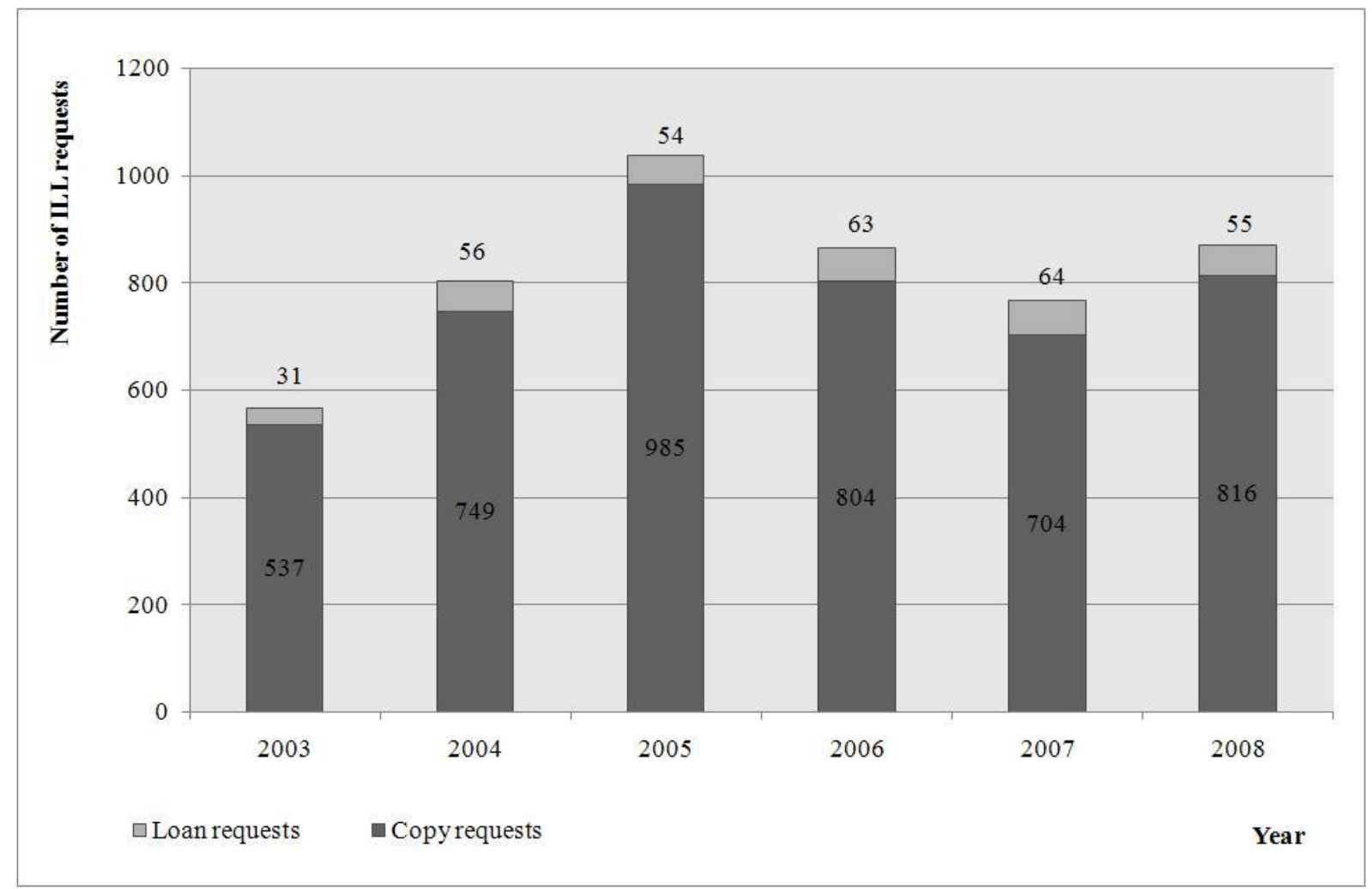

Figure 2: Number of ILL requests that RBI Library received in a 6year period from RBI employees

The survey revealed a surprisingly high percentage of requests cancelled due to the availability of items in the Library $(21.8 \%)$. Although previously conducted surveys in other libraries have shown that users also submit request for items owned or accessible in the library, cancellation rates fluctuate from a much lower 6-7\%, (Reycraft, 2010; Yontz et al., 2000) to a pretty high 17\%-18\%, (McGuigan and Russell, 2010; O'Brien, 2004). The main reason for such a high cancellation rate could be the obsolescence of the RBI library catalogues. Until recently (September 2009), the RBI Library lacked adequate library software, and therefore users encountered problems in finding a specific item; as a result requests for items available in the Library were submitted. In addition, one part of the library collection was not computer-catalogued until 2006, and thus there was no record of those items in the online catalogue. In 2009, Koha - an integrated library system - was implemented, and the problem was solved partially because the monograph catalogue is now up to date; however the serials database will not be fully incorporated until the end of 2010, (Macan, 2009). The full effectiveness of catalogue retrieval will be accomplished with the implementation of a federated search tool. This will enable searching of multiple resources simultaneously, thus hopefully reducing ILL requests for library owned items. As a result of this analysis and as an attempt to the number of ILL requests for documents which are available in the RBI Library, it was decided to educate users in information searching, the use of Library services and in new technologies. So at the beginning of 2010, the RBI Library started a series of lectures twice a month called 'Short Educational Library Seminars'.

Of the 3,848 legitimate ILL requests submitted (3,574 copy, 274 loan), 3,650 were fulfilled $(94.9 \%)$, of which 3,400 (93.2\%) were for copies and $250(6.8 \%)$ for loans. In the six 
year period, the average annual number of requests was 641 (595 copies, 46 loans). Figure 3 shows the number of requests per year and the lowest number of requests was registered in 2003 (441), which can be attributed to users needing to adjust to the new system - SEND. The highest number of requests was in 2005 (846). Since there was no significant cancellation of journals in that year, it can be explained by specific research subjects and targeted group of journals not available at the library. This could be verified by subject analysis and the analysis of the age of references, but it is not the aim of this survey.

In the six year period, an increase in the number of requests occurs three times (2003/4; 2004/5 and 2007/8) and a decrease twice (2005/6 and 2006/7). The failure rate decreases constantly each year, except 2005, when a slight increase is noted; so the failure rate decreased from $12.5 \%$ in 2003 to only $0.8 \%$ in 2008 which demonstrates the aptness and expertise of RBI Library ILL service (See Figure 3). Also, the cooperation with EURASLIC/IAMSLIC libraries can take the credit for this better performance.

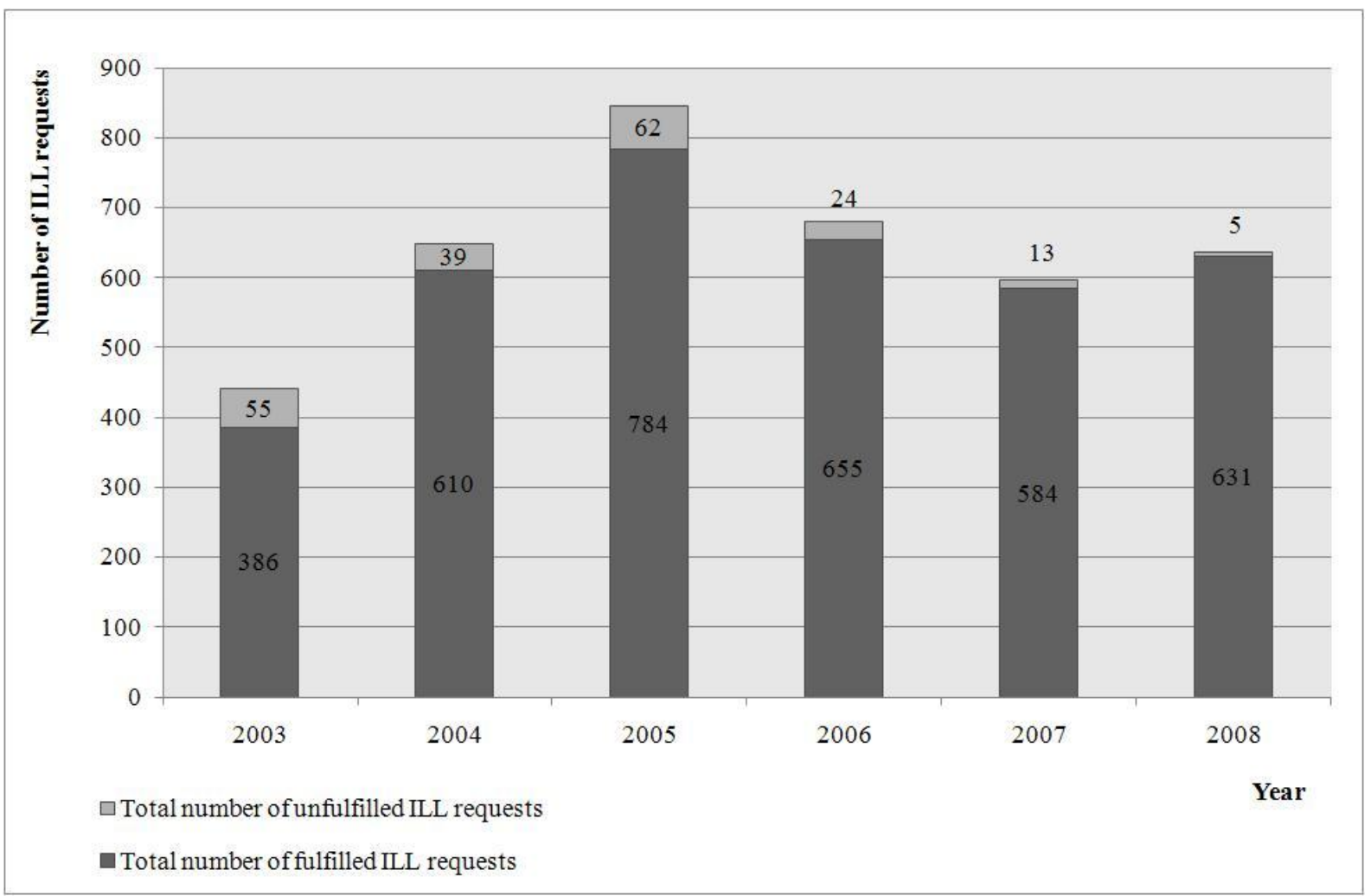

Figure 3: Total number of fulfilled and unfulfilled ILL requests from 2003 to 2008

Figures 4 and 5 show the number of fulfilled and unfulfilled ILL requests according to copy requests and loan request. 


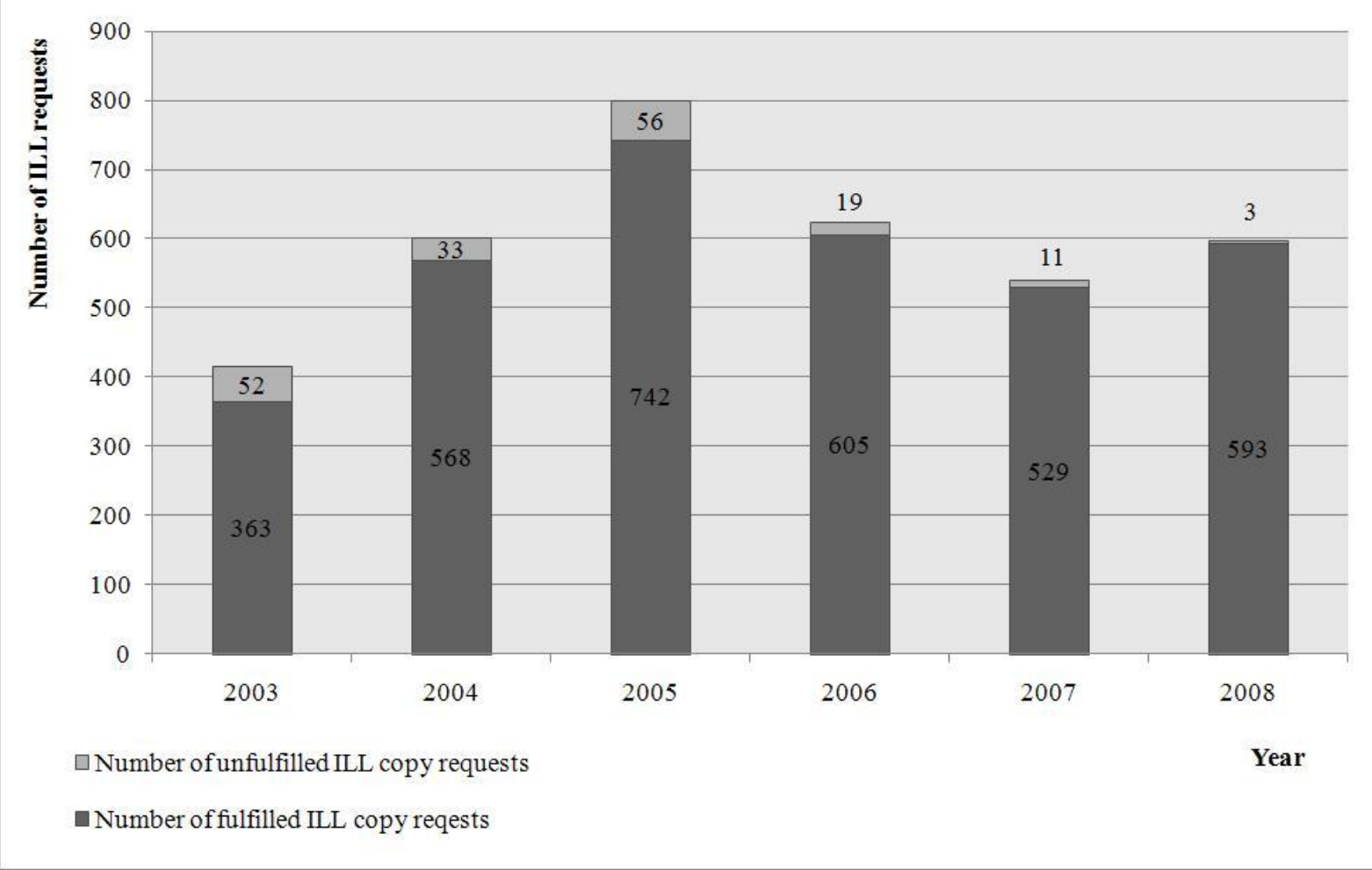

Figure 4: Total number of fulfilled and unfulfilled copy requests from 2003 to 2008

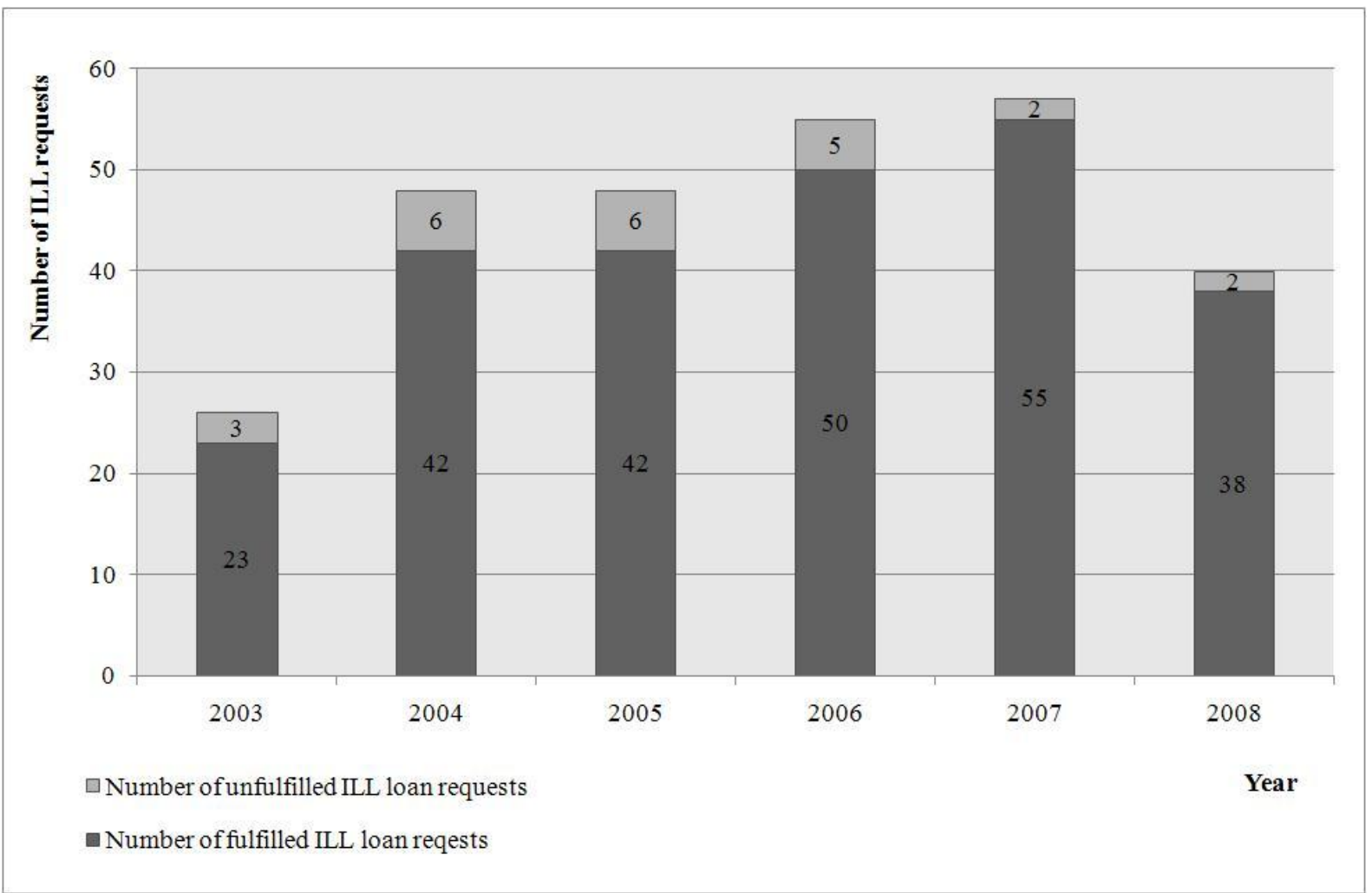

Figure 5: Total number of fulfilled and unfulfilled loan requests from 2003 to 2008

2.3.1. Analysis according to the lending libraries 
Of the 3650 fulfilled ILL requests, 1,401 (38.4\%) were obtained from libraries in Croatia, while 2,249 (61.6\%) were from libraries abroad. Loan requests are more frequently acquired from libraries abroad - 83.2\% (208) of all fulfilled loan requests were acquired from libraries abroad, while at the same time the percentage for copy requests is lower - $60 \%$ (2041). Concerning requests fulfilled within CSIS libraries, the majority are fulfilled within Natural Sciences $(1,074)$, followed by Biomedical Sciences (256), which is expected since this reflects the scientific research interests at the Institute.

During the study period, a substantial number $(41.5 \%)$ of ILL requests $(1,515)$ were obtained through SUBITO. This is followed by the Central Chemical library, University of Zagreb with 498 requests fulfilled (13.6\%) and TIB-Hannover with 277 (7.6\%) requests (See Table 1). The same ranking is for the copy requests alone (Table 2), but it differs for the loan requests (See Table 3).

\begin{tabular}{|l|c|c|c|c|c|c|c|}
\hline Library / Year & $\mathbf{2 0 0 3}$ & $\mathbf{2 0 0 4}$ & $\mathbf{2 0 0 5}$ & $\mathbf{2 0 0 6}$ & $\mathbf{2 0 0 7}$ & $\mathbf{2 0 0 8}$ & TOTAL \\
\hline \hline SUBITO & 0 & 182 & 449 & 365 & 175 & 244 & 1,515 \\
\hline Faculty of Science - Central Chemical Library & 90 & 81 & 74 & 55 & 71 & 127 & 498 \\
\hline TIB-Hannover & 90 & 115 & 18 & 33 & 10 & 11 & 277 \\
\hline British Library & 81 & 57 & 14 & 12 & 37 & 15 & 216 \\
\hline IAMSLIC & 0 & 0 & 0 & 1 & 36 & 108 & 145 \\
\hline Central Medical Library & 38 & 26 & 30 & 19 & 13 & 10 & 136 \\
\hline INA's library & 18 & 4 & 32 & 17 & 19 & 8 & 98 \\
\hline Institute of Oceanography and Fisheries & 5 & 8 & 30 & 22 & 21 & 10 & 96 \\
\hline $\begin{array}{l}\text { Faculty of Pharmacy and Biochemistry, } \\
\text { Zagreb }\end{array}$ & 7 & 8 & 26 & 15 & 8 & 17 & 81 \\
\hline $\begin{array}{l}\text { Faculty of Science - Department of } \\
\text { Geophysics, Library }\end{array}$ & 1 & 17 & 7 & 11 & 17 & 14 & 67 \\
\hline
\end{tabular}

Table 1: Top 10 lending libraries for the period 2003 to 2008 in total

\begin{tabular}{|l|c|c|c|c|c|c|c|}
\hline Library / Year & $\mathbf{2 0 0 3}$ & $\mathbf{2 0 0 4}$ & $\mathbf{2 0 0 5}$ & $\mathbf{2 0 0 6}$ & $\mathbf{2 0 0 7}$ & $\mathbf{2 0 0 8}$ & TOTAL \\
\hline \hline SUBITO & 0 & 179 & 440 & 343 & 248 & 217 & 1,427 \\
\hline Faculty of Science - Central Chemical Library & 89 & 79 & 73 & 55 & 71 & 127 & 494 \\
\hline TIB-Hannover & 80 & 100 & 6 & 18 & 8 & 11 & 223 \\
\hline British Library & 70 & 39 & 4 & 7 & 22 & 9 & 151 \\
\hline IAMSLIC & 0 & 0 & 0 & 1 & 36 & 108 & 145 \\
\hline Central Medical Library & 38 & 26 & 30 & 19 & 13 & 10 & 136 \\
\hline INA's library & 18 & 4 & 32 & 17 & 19 & 8 & 98 \\
\hline Institute of Oceanography and Fisheries & 5 & 7 & 30 & 20 & 21 & 10 & 93 \\
\hline $\begin{array}{l}\text { Faculty of Pharmacy and Biochemistry, } \\
\text { Zagreb }\end{array}$ & 7 & 8 & 26 & 15 & 8 & 17 & 81 \\
\hline $\begin{array}{l}\text { Faculty of Science - Department of } \\
\text { Geophysics, Library }\end{array}$ & 1 & 17 & 7 & 11 & 16 & 14 & 66 \\
\hline
\end{tabular}

Table 2: Top 10 lending libraries for the period 2003 to 2008 for copy requests 


\begin{tabular}{|l|c|c|c|c|c|c|c|}
\hline Library / Year & $\mathbf{2 0 0 3}$ & $\mathbf{2 0 0 4}$ & $\mathbf{2 0 0 5}$ & $\mathbf{2 0 0 6}$ & $\mathbf{2 0 0 7}$ & $\mathbf{2 0 0 8}$ & TOTAL \\
\hline \hline SUBITO & 0 & 3 & 9 & 22 & 27 & 27 & 88 \\
\hline British Library & 11 & 18 & 10 & 5 & 15 & 6 & 65 \\
\hline TIB-Hannover & 10 & 15 & 12 & 15 & 2 & 0 & 54 \\
\hline $\begin{array}{l}\text { Faculty of Chemical Engineering and } \\
\text { Technology - Library }\end{array}$ & 0 & 0 & 3 & 1 & 2 & 4 & 10 \\
\hline $\begin{array}{l}\text { Faculty of Mechanical Engineering and Naval } \\
\text { Architecture - Library, Zagreb }\end{array}$ & 0 & 2 & 1 & 2 & 0 & 0 & 5 \\
\hline Faculty of Science - Central Chemical Library & 1 & 2 & 1 & 0 & 0 & 0 & 4 \\
\hline $\begin{array}{l}\text { Faculty of Science - Central Library for } \\
\text { Physics }\end{array}$ & 1 & 0 & 0 & 1 & 2 & 0 & 4 \\
\hline Institute of Oceanography and Fisheries & 0 & 1 & 0 & 2 & 0 & 0 & 3 \\
\hline Končar - Library & 0 & 0 & 2 & 0 & 0 & 0 & 2 \\
\hline $\begin{array}{l}\text { Faculty of Science - Central Mathematical } \\
\text { Library }\end{array}$ & 0 & 0 & 0 & 0 & 2 & 0 & 2 \\
\hline
\end{tabular}

Table 3: Top 10 lending libraries for the period 2003 to 2008 for loan requests

\subsubsection{Interlibrary loan analysis according to the payment scheme}

While submitting requests through SEND, users can choose to order items exclusively free of charge (paying just handling fees) or approve a fee based order (mostly from abroad), in case it is not available free of charge. Of 4,918 ILL requests, 3,903 (79.4\%) were approved for orders that will be charged, comprising 3,638 copies and 265 loans. If the requests for items available at the library (cancelled requests) are excluded, then the approval rate was even higher; of 3,848 ILL requests, 3,141 (81.6\%) were approved for fee based orders, comprising 2,906 copies and 235 loans. The fulfillment rate is higher for the fee based requests; of 3,141 requests, 3,093 (98.5\%) were fulfilled comprising 2,873 copies and 220 loans. The fulfillment rate is lower for the requests ordered only if free of charge - of 707 requests, 557 (78.8\%) were fulfilled, comprising 527 copies and 30 loans. Although 3,141 ILL requests were approved for fee based acquisition, over one third of them were acquired free of charge $(\mathrm{N}=907)$, comprising 12 loans and 895 copies.

A comparison was made for the items acquired free of charge on a reciprocal basis and those fee-based. The results show that 1,565 items were acquired free of charge while 2,085 were fee based. In the last two years, an increase in items acquired free of charge has been noticed, so in 2008, for the first time after the cooperation with SUBITO started in 2004, the library acquired more items free than fee (See Figure 6 and 7). 


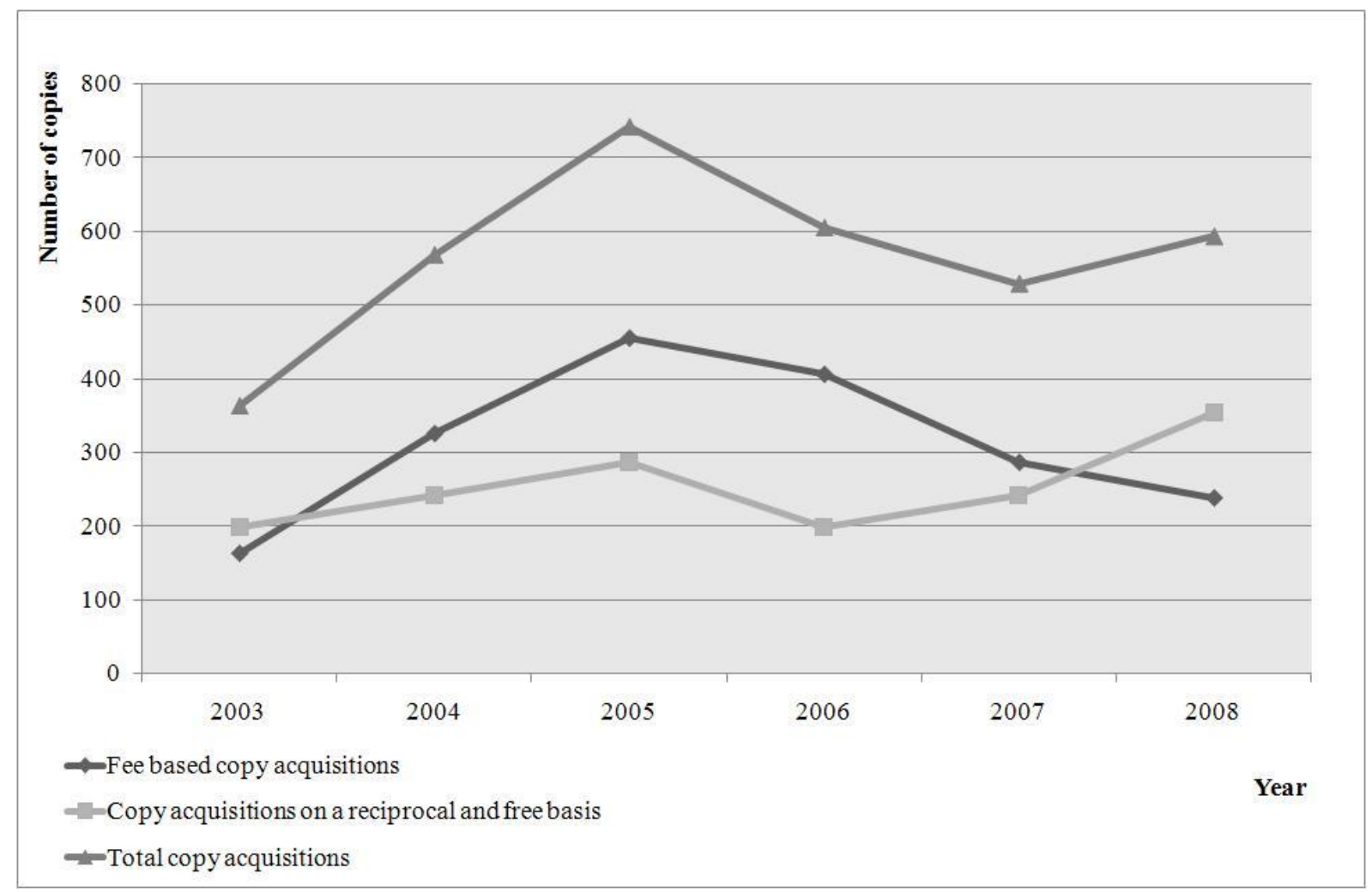

Figure 6: Number of fulfilled ILL copy requests from 2003 to 2008 by the cost of acquisition

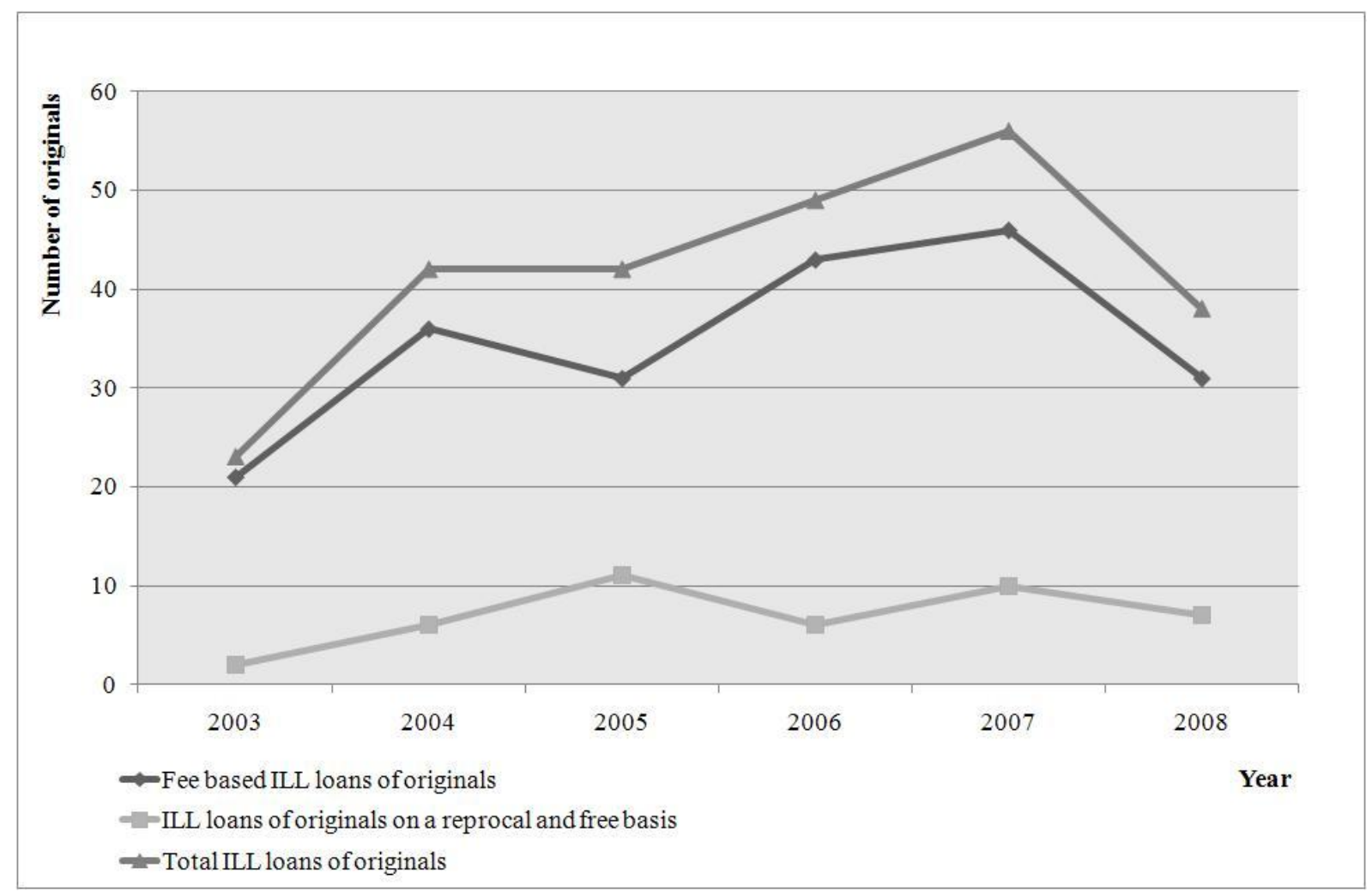

Figure 7: Number of fulfilled ILL loan requests from 2003 to 2008 by the cost of acquisition

If this trend continues, we can expect that more items will be acquired free of charge than fee based. This can be attributed to the cooperation with member libraries of 
EURASLIC/IAMSLIC Association, confirmed by its third ranking position in 2008 and the fourth ranking position for the six year period, although its Union List of Serials only began to be used at the end of 2006 (See Table 1).

Thus, if the percentages of copy requests and loan requests acquired free of charge are compared separately, it shows that $44.8 \%(1,523)$ of copy requests are acquired free of charge, unlike loan requests, where the percentage is pretty low $16.8 \%$ (42). This can be explained by the specific subject area of requested books that can rarely be found in other Croatian academic and research libraries.

\subsubsection{Processing and delivery time}

The processing time and the delivery time were analyzed and shown by working days. The processing time is counted from when a request is submitted online to when the library orders the item from another library, regardless of whether the request is sent to more than one library. The delivery time includes the time from when the request is submitted, to when the item is delivered or a negative answer has been sent in those cases when the request could not be fulfilled.

It should also be noted that "one working day" means that the request is processed on the same day it has been submitted. SEND is at the users' disposal 24 hours per day, meaning that requests can be submitted after library working hours, and the librarian processes the request the following day which adds one more processing day to the analysis. Incomplete and incorrect bibliographic information as well as hard to locate items increase the processing time and therefore medians are included in the analysis.

Considering all ILL requests (fulfilled and those unfulfilled or cancelled), the processing time is 2.2 working days (median $=2$ ). The average processing time for loan requests is 2.6 (median $=2$ ) and 2.2 (median $=2$ ) working days for copy requests.

The delivery time for all requests is 6.0 working days (median $=4$ ), but it takes more time for loans (average $=11.6$; median $=7$ ) than for copies (average $=5.6$; median $=4$ ).

If only the fulfilled ILL requests are taken into consideration, the average delivery time is 6.4 working days for copies (median =4) and 13.2 working days for loans (median = 8). Other similar surveys have shown about the same delivery time (Jackson, 2004; Reighart and Oberlander, 2008). Figure 8 shows the trend in average delivery time. 


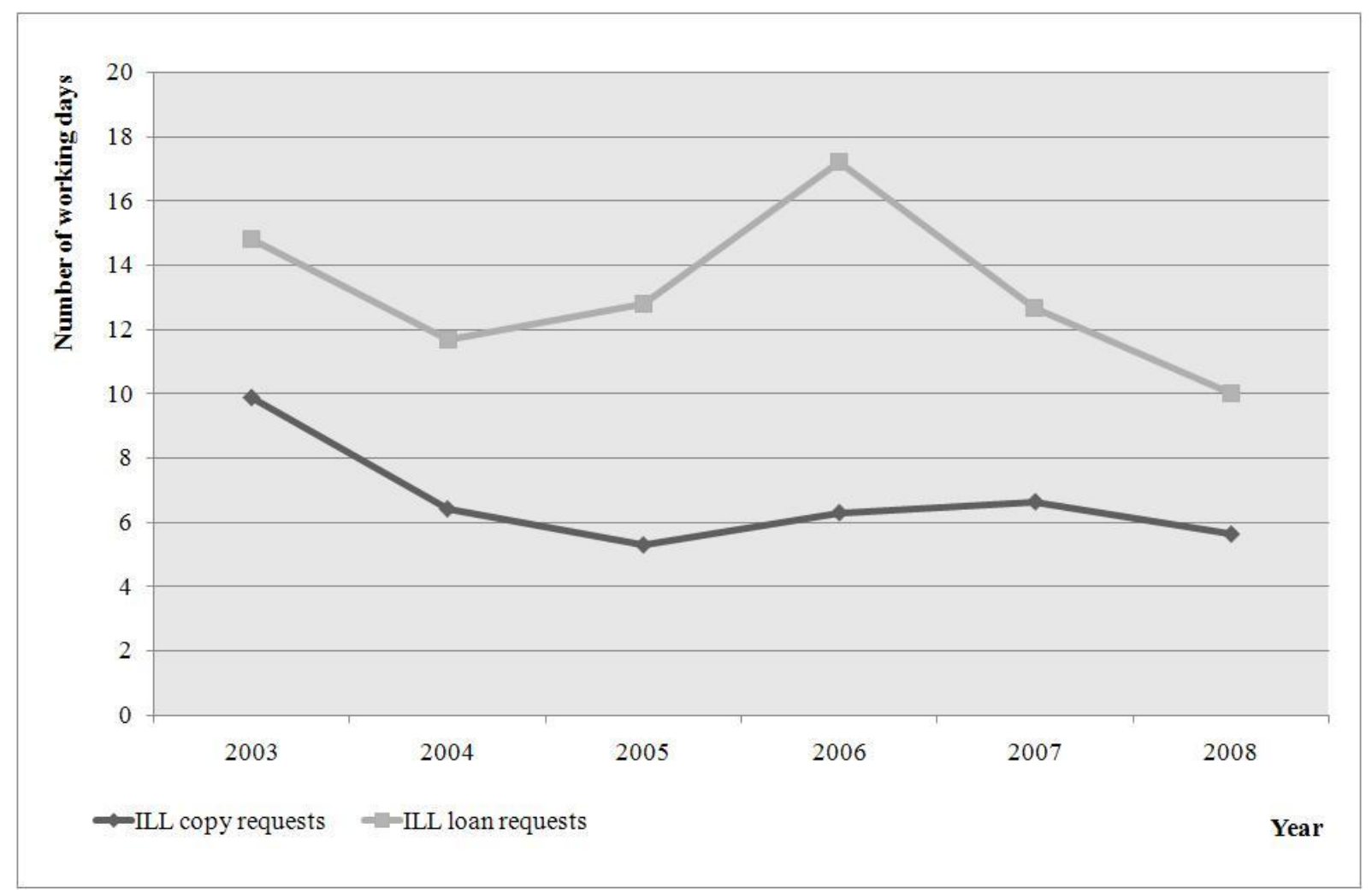

Figure 8: Average delivery time for ILL copy and loan requests 2003-2008

The survey showed that SUBITO had the fastest delivery time (average 2.7 working days; median $=2$ ), followed by TIBORDER (average $=4.0$; median $=3$ ) and IAMSLIC (average $=4.0$; median $=2$ ). When it comes to loan requests, the fastest delivery time is for libraries within Croatia: Faculty of Science - Central Chemical Library and Faculty of Mechanical Engineering and Naval Architecture (average =6), while for foreign libraries, the delivery time is higher $($ TIBORDER $=9.2$; $\mathrm{SUBITO}=10.3$; British Library $=11.5$ ).

As there were no previous surveys on the processing and delivery time at the RBI Library, there is no possibility of comparing the obtained results. However, Borić (Borić, 1999) mentions in her article the approximate processing and delivery time. Thus, the delivery time within Croatia was 10 days in 1999, the same as from Slovenia (Central Medical Library), while from the British Library it was 7-10 days, whereas from Deutsche Zentralbibliothek für Medizin, Köln and TIB-Hannover it took as long as a month. From the given data, albeit approximate, it is evident that at the beginning of the $21^{\text {st }}$ century, owing to the computerization of library services the ILL service becomes more efficient especially for the copy requests from abroad that are delivered on the same day as .pdf articles.

\section{Conclusion}

In 1994, Croatian academic and research libraries created a resource sharing service called the Croatian Sciences Information System project (CSIS). Among other things, it was agreed that member libraries of CSIS exchange documents via ILL free of charge on a reciprocal basis. When the project ended and most of the activities connected with it ceased, 
obsolete library catalogues and union library catalogues were left behind, which is the reason why a great part of library collections was hidden from the eyes of the users making it one of the biggest obstacles in establishing a good ILL service. In the last few years, the implementation of various integrated library systems in Croatian libraries has started with more or less success (Koha, Voyager, Aleph, Zaki, etc.), and time will tell whether their implementation will lead to better library and union catalogues, and thus improve the infrastructure for ILL.

RBI Library has offered ILL services to its users from its inception. The service has been modernized by developing a web-based application for online ordering of documents called - SEND. Constant efforts have been made to decrease delivery time as well as decrease document delivery prices. Even though the total number of journals available to the RBI staff has increased dramatically over the years, ILL continues to play a significant role among library services.

This survey showed that over a fifth of ILL requests submitted by RBI staff via SEND were cancelled because those documents were available in the RBI Library collection. This highlighted the need for additional user education in information searching and the justification for the short educational library seminars that started in 2010.

With time, the RBI Library has improved ILL to reach very high standards of efficiency - in $200387.5 \%$ of all requests were successfully fulfilled and by 2008 this had improved to an impressive $99.2 \%$. Almost $40 \%$ of all ILL requests were acquired from Croatian libraries free of charge, and within the last few years, free reciprocal ILL has been enabled from the libraries abroad as well. The number of copies acquired free of charge has grown constantly (except in 2005/6) and in 2008, for the first time in the analyzed period, the Library acquired more documents free of charge than fee based. When documents are acquired free of charge, the delivery time is usually longer, but despite that, the decrease of average delivery time during the six year period is visible.

It is very likely that the ILL service will keep an important place among RBI Library services in the future, especially if the current economic downturn in Croatia continues accompanied by an increase in journal and database prices which lead to constant library budget cuts and to subscription cancellation. This kind of situation is not sustainable in the long run and the libraries are hoping that the solution for this problem lies in the Open Access Initiative and Institutional Repositories.

This survey has shown that the RBI Library has a very well developed and efficient ILL service. Further research on this topic should be focused on the most ordered titles of books and journals and to the calculation of cost-effectiveness of subscribing for the mostordered titles. It would also be interesting to analyze the second part of the RBI Library ILL service - ILL requests received from other libraries and the ratio between the sent and the received ILL requests between libraries with which the RBI Library has an agreement on ILL on a reciprocal basis. 


\section{References:}

1. Borić, V. (1999), Knjižnica knjižnici - renesansa međuknjižnične posudbe, Kemija u industriji, Vol. 48 No.2, pp. 67-68.

2. Borić, V.and Pranjić, M. (2003), Novi program za međuknjižničnu posudbu SEND (Sustav elektroničke narudžbe dokumenata), Ruđer : znanstveno glasilo Instituta "Ruđer Bošković, Vol. 4 No. 3, pp. 10-11.

3. Crkvenčić-Bojić, J. (Editor-in-Chief), (2009), Statistical Yearbook of the Republic of Croatia 2009, Central Boreau of Statistics of the Republic of Croatia, Zagreb, available at: URL: http://www.dzs.hr/Hrv_Eng/ljetopis/2009/00-sadrzaj.htm (accessed 9 August, 2010).

4. Echeverria, M. and Barredo, P. (2005), Online journals: their impact on document delivery, Interlending \& Document Supply, Vol. 33 No. 3, pp.145-149.

5. Glenn S. McGuigan; Robert D. Russell. (2008), The Business of Academic Publishing: A Strategic Analysis of the Academic Journal Publishing Industry and its Impact on the Future of Scholarly Publishing // Electronic Journal of Academic and Special Librarianship 9, 3. http://southernlibrarianship.icaap.org/content/v09n03/mcguigan_g01.htm) (accessed 9 June, 2010).

6. Jackson, M. E. (2004), Will electronic journals eliminate the need for ILL?, Interlending \& Document Supply, Vol. 32 No. 3, pp. 192-193.

7. Konjević, S. (2009), SEND - Sustav elektroničke nabave dokumenata, Kemija u industriji, Vol. 58 No. 3, pp. 130-132.

8. Macan, B. (2009), Novi mrežni katalog knjiga Knjižnice Instituta "Ruđer Bošković", Kemija u industriji, Vol. 58 No.10, pp. 464-468.

9. Mayer, M. (2008), Međuknjižnična posudba - što, zašto, kako, pošto?, Kemija u industriji, Vol. 57 No. 7-8, pp. 380-382.

10. McGuigan, G. S. and Russell, R. D. (2008). The Business of Academic Publishing: A Strategic Analysis of the Academic Journal Publishing Industry and its Impact on the Future of Scholarly Publishing, Electronic Journal of Academic and Special Librarianship 9, 3, available at: http:southernlibrarianship.icaap.org/content/v09n03/mcguigan_g01.html (accessed 25 March, 2010).

11. Mihalić, M. (2009), Sustav elektroničke nabave dokumenata (SEND) ili kako olakšati i ubrzati međuknjižničnu posudbu, Uspostava kvalitete u specijalnim i visokoškolskim knjižnicama - knjižnice u bolonjskom okruženju: zbornik radova : 10. dani specijalnih i visokoškolskih knjižnica, Opatija, 2008, Hrvatsko knjižničarsko društvo, Zagreb, pp. 157-170.

12. O'Brien, K. (2004), Cancelled Requests: A Study of Interlibrary Loan Requests for Items Held in a Medical Library Collection, Medical Reference Services Qarterly, Vol. 23 No.3, pp. 17-23.

13. Reighart, R. and Oberlander, C. (2008) Exploring the future of interlibrary loan: generalizing the experience of the University of Virginia, USA, Interlending \& Document Supply, Vol. 36 No.3, pp. 184-190. 
14. Reycraft, K. (2010), Interlibrary loan requests canceled due to availability: problem or opportunity Journal of Interlibrary Loan, Document Delivery \& Electronic Reserve, Vol. 20 pp. 33-42.

15. Pivac, N. (Editor) (2009), Ruđer Bošković Institute Annual Report 2008, Ruđer Bošković Institute, Zagreb.

16. Topolčić, V.and Stojanovski, J. and Ražem, D. (1981a). Biblioteka Instituta "Ruđer Bošković". I. Koje časopise najviše traže vanjski korisnici?, 8. savjetovanje o naučnim i stručnim publikacijama i polupublikacijama, October 14-15, Zagreb (poster).

17. Topolčić, V.and Stojanovski, J. and Ražem, D. (1981b). Biblioteka Instituta "Ruđer Bošković". II. Što našim suradnicima manjka u fondu tekuće periodike? 8. savjetovanje o naučnim i stručnim publikacijama i polupublikacijama, October14-15, Zagreb (poster).

18. Wiley, L. and Chrzastowski, T. E. (2005), The impact of electronic journals on interlibrary lending: A longitudinal study of statewide interlibrary loan article sharing in Illinois, Library Collections, Acquisitions, \& Technical Services, Vol. 29 pp. 364381.

19. Yontz E. and Williams P. and Carey J. A. (2000), Interlibrary Loan Requests for Locally Held Items: Why Aren't They Using What we've Got? / Journal of Interlibrary Loan, Document Delivery \& Information Supply, Vol. 11 (1) pp.119-128.

20. Yue, P. W. and Syring, M. L. (2004), Usage of electronic journals and their effect on interlibrary loan: A case study at the University of Nevada, Reno, Library Collections, Acquisitions, \& Technical Services, Vol. 28, pp. 420-432. 